\title{
GRANICA UKRAIŃSKO-ROSYJSKA WE WSPÓŁCZESNYCH STOSUNKACH UKRAINY I FEDERACJI ROSYJSKIEJ
}

$\mathrm{O}$ d rozwoju stosunków Ukrainy i Federacji Rosyjskiej zależy dalszy bieg wydarzeń na postradzieckiej przestrzeni oraz w Europie Środkowo - Wschodniej. W interesie całej Europy powinno być, aby kraje te weszły na szybką drogę demokratycznych i rynkowych reform, a także by współpracowały ze sobą na zasadach powszechnie przyjętych w prawie i zwyczaju międzynarodowym. Tymczasem w 13 lat po rozpadzie Związku Radzieckiego granica między Ukrainą i Rosją de facto nie istnieje. Ukraińsko-rosyjskie pogranicze jest w związku z tym jednym z głównych szlaków nielegalnych migrantów do krajów Europy Zachodniej oraz źródłem dochodów dla pojedynczych i zorganizowanych grup przemytniczych. Aby jednak rozwiązać problem wspólnej granicy zarówno Moskwa jak i Kijów powinny nie tylko przyjąć ogólnie obowiązujące w dyplomacji zasady współpracy, ale i pozbyć się ciężaru przeszłości, który nie pozwala im współpracować na jasnych i równych warunkach. Rosjanie nigdy nie traktowali Ukrainy jak obcego kraju, uważając ją za swoje Kresy Południowe. Z Ukrainy pochodzili m. in. Gogol, Czechow, Czajkowski, Riepin i Bułhakow - współtwórcy wielkości kultury rosyjskiej. Kijów to dla Rosjan miasto o znaczeniu symbolicznym, Połtawa jest miejscem symbolicznych narodzin wielkości Cesarstwa Rosyjskiego, a Sewastopol kojarzy się Rosjanom z historyczna obrona tego miasta w 1855 r. Na Ukrainie od pokoleń mieszka duża liczba etnicznych Rosjan. Powstanie suwerennej Ukrainy w roku 1991 było dla Moskwy wstrząsem, a także imperialnym wyzwaniem. Aleksander Sołżenicyn oddzielenie się Ukrainy od Rosji przyrównał do podziału Niemiec po drugiej wojnie światowej. Społeczeństwo i elita rosyjska były przekonane o tymczasowości państwowości ukraińskiej, co wywoływało i wywołuje po dziś dzień lekceważący stosunek do niepodległej Ukrainy. Z drugiej strony, Ukraińcy - żyjący z Rosjanami w 
jednym państwie przez trzy stulecia, nie bardzo potrafią współpracować z Moskwą na innych zasadach niż w przeszłości i wciąż uczą się samodzielności. Poza tym gorzko doświadczeni przez historię, która zazwyczaj pisali Rosjanie, w swoim patriotycznym (często pseudopatriotycznym) podejściu do rosyjskich spraw, czasami nie umieja dostrzec potrzeby większej pragmatyzacji stosunków z Moskwą. Poniższy tekst jest próbą analizy stosunków ukraińsko-rosyjskich przez pryzmat wspólnych problemów granicznych. Składa się z dwóch części: pierwsza opisuje kwestie powiązane $\mathrm{z}$ rosyjsko-ukraińskimi sporami granicznymi, a druga jest próbą oceny całości stosunków Ukrainy i Federacji Rosyjskiej w świetle sytuacji na granicy.

Kwestia granic, w tym granicy ukraińsko-rosyjskiej, była tematem licznych spotkań dyplomatów na forum Wspólnoty Niepodległych Państw (WNP). Sprawa ta była poruszana już pod koniec grudnia $1991 \mathrm{r}$. na pierwszym oficjalnym szczycie WNP w Mińsku, kiedy niepodległe republiki zgodziły się utrzymać wspólną kontrolę granic zewnętrznych Wspólnoty z państwami trzecimi ${ }^{1}$. Jednak ze względu na ostry sprzeciw władz w Kijowie, które nie podporządkowały swoich służb granicznych kolektywnemu kierownictwu, mińskie ustalenia nie weszły w życie. Zasady z Mińska zostały anulowane w lipcu 1992 r., gdy powołano radę koordynacyjną zwierzchników służb granicznych poszczególnych państw. W październiku tegoż roku na szczycie WNP w Biszkeku wypracowano porozumienie o wspólpracy na rzecz zapewnienia stabilności zewnętrznym granicom Wspólnoty. Podobnie jednak jak wcześniej Kijów odrzucił i te ustalenia. Zwraca uwagę fakt, że te pierwsze nieudolne próby uregulowania kwestii granicznych dotyczyły granic zewnętrznych byłego ZSRR, a nie granic między republikami. Pierwsze sześć lat po rozpadzie Związku Radzieckiego w rosyjskoukraińskich stosunkach zdominowały spory o status Krymu, Flotę Czarnomorską i postradziecką broń nuklearną ${ }^{2}$. Aż do końca maja 1997 r., gdy podpisano układ definitywnie kończacy te spory, relacje Kijowa i Moskwy były bardzo napięte i o uregulowaniu spraw związanych ze wspólną granicą nie mogło być nawet mowy. Problem ten stał się tematem rzeczowych rozmów dopiero po roku 1999, kiedy do władzy w Rosji doszedł Władimir Putin. Co prawda już w 1998 r zdecydowano się na powołanie komisji delimitacyjnej, ale prace komisji właściwie nie posuwały się naprzód.

\footnotetext{
${ }^{1}$ A. Eberhardt, Problem wspólnej granicy w stosunkach rosyjsko-ukraińskich, „Polski Przegląd Dyplomatyczny", marzec-kwiecień 2003, nr 2(12) s. 42.

2 Zob. J. Kozakiewicz, Rosja w polityce niepodległej Ukerainy, Warszawa 1999.
} 
Rosyjsko-ukraińska granica lądowa liczy 2063 km i rozciaga się od Zatoki Taganrodzkiej (będącej częścią akwenu Morza Azowskiego) po kopiec Przyjaźń na północny-wschód od Czernihowa. Przy czym rozgraniczenie to jest sztuczne, nie mające silnych uzasadnień historycznych i co bardzo ważne nie będące nigdy wcześniej granica państwowa ${ }^{3}$. W czasach sowieckich pomimo formalnego istnienia granicy między Ukraińską Socjalistyczną Republiką Radziecką (USRR), a Rosyjską Socjalistyczną Republiką Radziecką (RSRR) nie przeprowadzono jej delimitacji, nie wspominając o demarkacji. Moskwa długo odmawiała podjęcia działań mających na celu rozwiązanie tego problemu także po rozpadzie ZSRR. Niedługo po przyjściu na fotel prezydenta Rosji W. Putina ogłoszono, że rozmowy w sprawie wspólnej granicy zostaną zakończone do końca 2001 roku. Z czasem jednak obie strony informowały o konieczności przedłużenia terminu zakończenia procesu delimitacji. Ostatecznie Porozumienie o granicy państwowej zostało podpisane przez obu prezydentów 28 stycznia 2003 r. ${ }^{4}$, a ratyfikowane przez Radę Najwyższą Ukrainy i parlament rosyjski w kwietniu 2004 r. Nie likwiduje to jednak potrzeby demarkacji (demarkacja - wyznaczenie granicy w terenie), co powoduje, że granica jest wciąż nieszczelna. Delimitacja w bardzo ograniczonym stopniu przekłada się na praktyczne kwestie związane z jej funkcjonowaniem. Co więcej z ust rosyjskich polityków często padaja słowa świadczące o niechęci do przeprowadzenia demarkacji.

Obecnie ukraińsko-rosyjska granica lądowa na całej długości jest obsadzona zaledwie czternastoma przejściami drogowymi i dwunastoma kolejowymi - punkty kontroli znajdują się średnio co ok. $60 \mathrm{~km}$. Wprawdzie porozumienia rządowe podpisane przez premierów Janukowycza i Kasjanowa mówią o tym, że ich liczba ma zostać podwojona, lecz, nawet wtedy, ominięcie kontroli granicznej nie będzie sprawiało większej trudności ${ }^{5}$. Poza tym watpliwą wydaje się być możliwość zrealizowania porozumień premierów bez pomocy finansowej ze strony Unii Europejskiej, a ta do tej pory zajęta była głównie uszczelnianiem swojej nowej wschodniej granicy. Strona ukraińska utrzymuje, że demarkacja zatrzymałaby (a co najmniej ograniczyła) potok nielegalnej migracji z państw Azji przez Ukrainę na Zachód. Szacunkowe dane mówią o tym, że rocznie ukraińsko-rosyjska granicę przekracza ok. 30 tys. nielegalnych migrantów ${ }^{6}$. Co więcej

\footnotetext{
${ }^{3}$ A. Eberhardt, dz. cyt., s. 43.

${ }^{4}$ В. Кравченко, Підводне каміння Азовсвкого Моря, „Азеркало тижня”, 22-28.02.2003.

${ }^{5}$ A. Eberhardt, dz. cyt., s. 44.

${ }^{6}$ Tamże.
} 
Ukraina nie ma podpisanej z Rosja umowy o readmisji, czego Moskwa wciąż odmawia. Umowa taka zobowiązywałaby stronę rosyjską do przyjmowania migrantów znad Dniepru, którzy wcześniej przybyli na Ukrainę z terytorium Rosji. Ukraińskim władzom zależy na wytyczeniu granicy w terenie także dlatego, by ograniczyć proceder kontrabandy mieszkańcy terenów przygranicznych zajmują się często przemytem cukru, alkoholu, papierosów czy benzyny, a zorganizowane grupy przestępcze szmugluja narkotyki i broń. Oficjalne dane mówią, że wspólnie rosyjskie i ukraińskie służby graniczne są w stanie zapobiec zaledwie co dziesiątej próbie przemytu. Problemem zarówno ukraińskiej jak i rosyjskiej gospodarki jest szara strefa, a utrzymywanie się takiego stanu rzeczy na granicy daje dodatkowe impulsy do jej rozwoju. Moskwa odrzucając pomysły demarkacji twierdzi, że jest to bardzo kosztowne przedsięwzięcie, a także, że miałaby negatywne skutki dla ludności przygranicznej, dla której oznaczać może utratę często jedynego źródła dochodu i utrudnienie w kontaktowaniu się z bliskimi żyjącymi po różnych stronach granicy. W rzeczywistości taka sytuacja przynosi ogromne straty budżetom obu państw. Rosyjskie władze postępując w sprawie rozgraniczenia z Ukraina i innymi krajami postsowieckimi musza liczyć się z wciąż obecną w Rosji nostalgią za Związkiem Radzieckim i starymi więziami z tymi państwami. Każde umocnienie się niezależności którejś z byłych republik postrzegane jest jako rosyjska porażka i prowadzi do utraty popularności rządzącej elity. Oprócz tego należy pamiętać, że zaprowadzenie normalnej sytuacji na ukraińsko-rosyjskiej granicy byłoby postrzegane negatywnie przez większość społeczeństwa ukraińskiego i rosyjskiego, którym taki stan rzeczy często odpowiada.

Podpisane w styczniu 2003 r. i ratyfikowane w kwietniu 2004 r. Porozumienie o granicy państwowej nie wywołuje sporów w przypadku rosyjsko-ukraińskiej granicy lądowej. O wiele więcej kontrowersji zawsze wywoływał problem wspólnej granicy morskiej. Spór o wytyczenie granicy na Morzu Azowskim i w Cieśninie Kerczeńskiej dotyka strategicznych interesów obu państw. Związane jest to $\mathrm{z}$ geostrategicznym położeniem akwenu, a także występowaniem w nim bogatych zasobów morza, a pod nim surowców (gazu ziemnego i ropy naftowej) ${ }^{7}$. Poza tym Morze Azowskie i Cieśnina Kerczeńska to podstawowy szlak wodny łączący europejską część Rosji z Morzem Czarnym i Śródziemnym. Jest to jedyne wyjście z dorzecza Donu i

\footnotetext{
${ }^{7}$ Złoża gazu ziemnego szacowane są na ok. 330 - 400 mld. m³. Część ekspertów uważa jednak, że gazu jest jeszcze więcej. Poza tym Morze Azowskie jest wyjątkowo bogate w zasoby ryb; Zob. A. Eberhardt, dz. cyt., s. 46.
} 
połączoną z nim kanałem Wołgi na ww. morza. Eksportowana produkcja hutnicza i przemysłu metalowego ukraińskiego Zagłębia Donieckiego przechodzi przede wszystkim przez nadazowskie porty Mariupol i Taganrog. Dla Kijowa sprawa podziału akwenu ma zasadnicze znaczenie również z innych powodów. Brak rozgraniczenia pozostawia nienaruszoną wielokilometrową „dziurę” w granicy, przez którą napływają nielegalni migranci, a brak podpisanej z Rosją umowy o readmisji powoduje, że Ukraina może być krajem gromadzącym nielegalnych migrantów. Poza tym brak granicy na Morzu Azowskim szkodzi ekonomicznym interesom Ukrainy - rosyjskie kutry, bowiem korzystaja z zasobów morza, jakie po rozgraniczeniu znalazłyby się po stronie ukraińskiej (bardziej zasobnej w ryby, ropę naftową i gaz ziemny - aż 90\% złóż gazu byłoby po stronie ukraińskiej). Kijów zawsze postulował przy tym przeprowadzenie granicy po dnie morza i po jego powierzchni, natomiast Moskwa tylko po dnie ${ }^{8}$.

Już w roku 1992 Ukraina wezwała Rosję do podjęcia działań mających na celu jak najszybszą delimitację Morza Azowskiego w oparciu o przepisy prawa międzynarodowego - czyli określenia przez oba kraje zasięgu swojego morza terytorialnego oraz rozgraniczenia akwenu na rosyjską i ukraińska wyłączną strefę ekonomiczną. Moskwa od początku opowiadała się jednak za zachowaniem statusu morza jako wód wewnętrznych podlegających wspólnemu wykorzystaniu. Zdaniem rosyjskich polityków, takie rozwiązanie byłoby w ekonomicznym i strategicznym interesie obu państw. Postulowana przez Kijów koncepcja podziału akwenu oznaczałaby częściowe umiędzynarodowienie, a Rosja obawia się tam obecności okrętów NATO. Rosjanie podkreślają, że rozgraniczenie doprowadziłoby do mniej efektywnego i racjonalnego wykorzystywania zasobów mineralnych i biologicznych oraz do utrudnienia walki z kłusownictwem, nielegalną migracja, przemytem broni i narkotyków. Sprawa rozgraniczenia nie jest do końca jasna z punktu widzenia prawa międzynarodowego. Strona ukraińska powołuje się na podstawowe zasady, które daja państwom możliwość ustanowienia morza terytorialnego o szerokości do 12 mil morskich oraz przylegającej do niego, liczącej maksymalnie 200 mil morskich (od linii podstawowych od linii najniższego stanu wody wzdłuż wybrzeża) wyłącznej strefy ekonomicznej ${ }^{9}$. Strony spieraja się o sposób wytyczenia linii, która rozgraniczałaby nakładające się dwustumilowe pasy ukraińskiej i

\footnotetext{
8 А. СаАовський, Київ наважився самостійно розмежувати Азовське Море, „Азеркало тижня”, 22-27.06.2002; W kwietniu 2004 r. strona rosyjska zgodziła się na pełne rozgraniczenie akwenu.

${ }^{9}$ R. Bierzanek, J. Symonides, Prawo międzynarodowe publiczne, Warszawa 1998, s. 211-235.
} 
rosyjskiej wyłącznej strefy ekonomicznej. Ukraina chce przeprowadzić tę linię w oparciu o zasadę tzw. linii środkowej - linii, której każdy punkt jest jednakowo oddalony od najbliższych punktów linii podstawowych obu stron. Zasada ta jest przyjęta $\mathrm{w}$ praktyce międzynarodowej, ale Konwencja o prawie morza zakłada jej obowiązywanie jedynie przy delimitacji morza terytorialnego. Przy określaniu granic wyłącznej strefy ekonomicznej pomiędzy państwami, których wybrzeża znajduja się naprzeciwko siebie, a tak jest w przypadku Morza Azowskiego, delimitacja powinna być przeprowadzona na mocy dwustronnego porozumienia ${ }^{10}$. Biorąc to pod uwage kluczowe znaczenie ma w tej kwestii ustalenie przez obie strony statusu morza oraz Cieśniny Kerczeńskiej.

Sprawa podziału Morza Azowskiego była rozpatrywana przez stała mieszaną komisję złożoną z przedstawicieli ministerstw spraw zagranicznych, obrony i służb granicznych. Kilkunastokrotne rundy negocjacji nie przynosiły jednak długo efektów. Pewien progres w rozwiązaniu sporu zanotowano po tym, gdy ukraiński rząd podją decyzję o samodzielnym rozgraniczeniu morza. Możliwość taką daje Kijowowi Konwencja ONZ prawa morskiego z 1982 r., która zezwala na ustanawianie terytorialnych wód o szerokości do $12 \mathrm{mil}^{11}$. W praktyce Ukraina nie podjęła działań w tym kierunku, ale od tego czasu Moskwa wykazywała większą elastyczność w negocjacjach. Efektem tego było Porozumienie o granicy państwowej ze stycznia 2003 r. Porozumienie to jest jednak dosyć kontrowersyjne dla obu stron. Jego punkt 5, dotyczący granicy morskiej, zawiera dosyć niejasny zapis w kwestii statusu morza. Zdania ekspertów są podzielone jeśli chodzi o to, czy zgodnie z tym punktem Ukraina zgodziła się na uznanie akwenu azowskiego za wewnętrzne wody dwóch państw, co bardzo odpowiadałoby stronie rosyjskiej $^{12}$. Istotne, że ukraińskie władze stoja nadal na stanowisku by Morze Azowskie zostało rozgraniczone zgodnie $\mathrm{z}$ koncepcja przedstawianą wcześniej. Poza tym uzgodnienia obu stron zostały zweryfikowane przez wydarzenia z drugiej połowy 2003 r. wokół Cieśniny Kerczeńskiej.

Częścia sporu o podział Morza Azowskiego jest spór o Cieśninę Kerczeńską ${ }^{13}$. Cieśnina ta oddziela należący do Ukrainy Półwysep Krym

\footnotetext{
10 A. Eberhardt, dz. cyt., s. 47.

11 А. Садовський, dz. cyt.

12 В. Кравченко, dz. cyt.

13 Przez cieśninę przeprowadzony jest Kanał Kerczeńsko-Jenikalski, którym przepływaja prawie wszystkie statki udające się na Morze Czarne lub w odwrotnym kierunku.
} 
od rosyjskiego Półwyspu Tamańskiego. Jest także jedynym torem wodnym łączącym azowski akwen i jego porty (ukraińskie - Mariupol i Kercz oraz rosyjskie - Taganrog, Rostów nad Donem, Azow, Jejsk, Primorsk - Achtorsk i Tiemriuk), a także porty śródlądowe dorzecza Donu i Wołgi z Morzem Czarnym i Śródziemnym. Transport przez cieśninę jest całkowicie kontrolowany przez stronę ukraińską - Kijów pobiera opłaty za usługi pilotów portowych oraz za tranzyt cieśniną (rocznie rosyjskie statki uiszczają ok. 15-16 miliardów dolarów do ukraińskiej kasy). Łącznie cieśninę przekracza rocznie ok. 9 tys. statków ${ }^{14}$. Moskwa była oczywiście przeciwna przeprowadzeniu granicy w cieśninie i opowiada się jednocześnie za tym by eksploatacją torów wodnych w cieśninie zajmowały się obie strony wspólnie. Dla rozgraniczenia cieśniny ogromne znaczenie ma status wyspy położonej w centralnej jej części - Tuzły. Tory wodne znajdują się pomiędzy wyspą, a Płw. Krym ${ }^{15}$. Zdaniem Kijowa Tuzła jest integralną częścią Ukrainy. Moskwa natomiast nigdy oficjalnie tego nie przyznała.

Geneza sporu o Tuzłę sięga lat dwudziestych. W pierwszej połowie trzeciej dekady dwudziestego wieku Tuzła była czterokilometrową mierzeją Płw. Tamańskiego wcinającą się w Cieśninę Kerczeńska. W roku 1925 ówczesne sowieckie władze zdecydowały jednak o tym, by przez mierzeję przekopać niewielki kanał tak, aby umożliwić rybakom wyjście na morze bez konieczności opływania mierzei. Kanał ten został z czasem znacznie pogłębiony, a mierzeja rozmyta w konsekwencji czego powstała wyspa, która znajdowała się pod administracja władz w Triemriuku na Płw. Tamańskim. Jednak na krótko przed wybuchem wojny niemiecko-sowieckiej w 1941 r. wysepka została wyłączona spod administracji triemriuckich władz i podporządkowana władzom w Kerczu na Krymie. Wówczas zarówno Krym, jak i Tamań, znajdowały się w granicach RFSRR. Lecz w 1954 r. wraz z przekazaniem Krymu USRR, Tuzła znalazła się pod ukraińską administracja. Taki stan rzeczy był potwierdzany wielokrotnie już po rozpadzie ZSRR w różnego rodzaju dokumentach: Układ między Ukraina i Federacja Rosyjska o dalszym rozwoju międzypaństwowych stosunków (1992 r.), Umowa o prazyjaźni, wspótpracy i partnerstwie (1997 r.), Uktad o stworzeniu

\footnotetext{
14 A. Eberhardt, dz. cyt., s. 49.

${ }^{15}$ Do niedawna istniały jeszcze dwa inne tory (tory nr 50 i 52). Znajdowały się one między Tuzła, a Półwyspem Tamańskim. Miały tylko 3 metry głębokości, co wykluczało możliwość korzystania z nich przez większe statki. Zostały jednak zasypane w związku z rozpoczęta przez Rosjan w końcu września 2003 r. budową grobli z Płw. Tamańskiego w kierunku Tuzy; zob. P. Kościński, Tama coraz bližej Kosy Tuzła, „Rzeczpospolita”, 22.10.2003.
} 
Wspólnoty Niepodlegtych Państw (1991 r.) czy też Deklaracji o przestrzeganiu suwerenności, jedności terytorialnej i nietykalności granic krajów WNP (1994 r. $)^{16}$.

Najistotniejsze i najbardziej aktualne dla sprawy Cieśniny Kerczeńskiej i Tuzły wydarzenia miały miejsce po 29 września 2003 r. Wtedy to strona rosyjska rozpoczęła budowę grobli z Płw. Tamańskiego w kierunku Tuzły ${ }^{17}$. Przez trzy tygodnie Rosjanie szli w kierunku wysepki w tempie jak sami określali - „szturmowym”. Groblę budowano nieprzerwanie w dzień i w nocy. Jak policzyli ukraińscy pogranicznicy co godzinę na nasyp wjeżdżało ok. stu kamazów załadowanych piaskiem i kamieniami. Przy budowie zatrudnionych było ok. tysiąc osób ${ }^{18}$. Co najbardziej istotne budowę rozpoczęto bez żadnego uprzedzenia o tym strony ukraińskiej. Przez pierwsze dni Kijów nie reagował sądząc, że są to zwykłe czynności związane z regulacja linii brzegowej. Gdy jednak grobla bardzo szybko zbliżyła się do Tuzły, ukraiński MSZ wystosował notę do MSZ - u Federacji Rosyjskiej z zapytaniem o cel działań w pobliżu wyspy. Moskwa jednak długo milczała. Jako pierwszy ze strony rosyjskiej na ten temat wypowiedzial się gubernator Kraju Krasnodarskiego Aleksander Tkaczow: „Wyspa jeszcze 80 lat temu stanowiła zakończenie mierzei ciagnącej się od rosyjskiego Płw. Tamańskiego" "19. Natomiast rosyjski MSZ, kiedy budowniczowie byli pół kilometra od Tuzły, zażądał od Kijowa dokumentów potwierdzających przynależność wyspy do Ukrainy. Ukraińscy dyplomaci odpowiedzieli, że nie będa udowadniać czegoś, co jest oczywiste. Rosyjskie media kontrolowane przez władzę powtarzały w tym czasie: „Ani w Kijowie, ani w Symferopolu (stolica Krymu - P.K.) nie posiadają dokumentów potwierdzających prawa Ukrainy do wyspy, a żadna granica w tym regionie nie była wyznaczana” ${ }^{20}$. Żołnierze ukraińskich wojsk pogranicznych zakwaterowani na Tuźle wychodzili na brzeg i ćwiczyli odparcie ataku tak, by Rosjanie ich widzieli ze swojej grobli. Za ich plecami ustawione były głośniki, które wykrzykiwały hasła z wbitych w piasek transparentów: „Przed wami przedstawiciele bratniego narodu słowiańskiego, nie doprowadzajcie do rozlewu krwi”. Telewizja rosyjska

\footnotetext{
${ }^{16}$ С. Солодкий, Аамбою по кордону, „Аень”, 11.10.2003; patrz także : A. Eberhardt, dz. cyt., s. 65; P. Kościński, dz. cyt.

${ }^{17}$ Niewiadomo, kogo uważać za stronę rosyjska - niejasne, bowiem jest, kto dał rozkaz o budowie: władze centralne w Moskwie czy lokalne w Krasnodarze?

18 W. Radziwinowicz, Ukraina jako gubernia, „Gazeta Wyborcza”, 3.11.2003.

19 Tamże.

20 Tamże.
} 
kwitowała te zdjęcia pogardliwymi komentarzami zapewniając, że Ukraina nie jest w stanie Rosji nic więcej przeciwstawić ${ }^{21}$.

6 października 2003 r. do Moskwy przybył minister spraw zagranicznych Ukrainy Kostiantyn Hryszczenko. Pomimo tego, że centralnym tematem rozmów była kwestia budowy grobli to istotnych ustaleń nie przyniosły. Ukraiński minister nie uzyskał odpowiedzi na pytania ani w jakim celu budowana jest grobla, ani z czyjej inicjatywy ja podjęto, ani kiedy zostanie przerwana. 22 października, gdy grobla była już bardzo blisko wyspy, prezydent Ukrainy Leonid Kuczma w związku z bardzo napiętą sytuacja przerwał wizytę w krajach Ameryki Łacińskiej, a premier Wiktor Janukowycz odwołał zaplanowane spotkania w Estonii i na Łotwie. Napięcie rozładowała dopiero rozmowa telefoniczna prezydentów Rosji i Ukrainy. W jej efekcie budowę przerwano, gdy do wyspy pozostawało 100 metrów $^{22}$.

Kilka dni później w Moskwie spotkali się premierzy Janukowycz i Michaił Kasjanow. Ustalono, że Ukraina wycofa swoich pograniczników z Tuzły, a Rosja nie będzie wznawiać budowy grobli. Premierzy opowiedzieli się za powołaniem wspólnej mieszanej komisji, która miałaby wyjaśnić zasadność budowy grobli ${ }^{23}$. Kiedy jednak sześć dni później do Kijowa przybył minister spraw zagranicznych Rosji Igor Iwanow, Janukowycz oficjalnie zaprzeczył jakoby zgodził się na wycofanie pograniczników z Tuzły ${ }^{24}$. Po spotkaniu Iwanow i jego ukraiński odpowiednik Hryszczenko wzięli udział w konferencji prasowej. Ukraiński dyplomata stwierdził, że Kijów nie jest na tyle naiwny by „kryzys tuzłyński” uważać za „,nieporozumienie” jak nazywali ten spór politycy rosyjscy. Iwanow podkreślił, że groblę budowano z myślą o regulacji linii brzegowej ${ }^{25}$. Jednocześnie podczas rozmów przedstawił dowody przynależności Tuzły do Rosji ${ }^{26}$. Najważniejszym efektem wizyty było podpisanie Wspólnego oświadczenia ministrów spraw zagranicznych Ukrainy $i$ Federacji Rosyjskiej. Zapewniono w nim o chęci rozwijania stosunków między państwami - strategicznymi partnerami na warunkach Porozumienia o prayjaźni, wspótpracy i partnerstwie z maja 1997 r.,

${ }^{21}$ P. Kościński, dz. cyt.

${ }^{22}$ М. Касьяненко, Зупинили на 100 метрів, „Аень”, 24.10.2003; W. Radziwinowicz, Na razie staneli, „Gazeta Wyborcza”, 24.10.2003.

23 Tenże, Palec na cynglu, „Gazeta Wyborcza”, 25-26. 10. 2003.

${ }^{24}$ В. Зам'ятін, Криза стратегіиного партнерства, „Аень”, 30.10.2003.

25 Т. Силіна, Поговорили, „Азеркало тижня”, 1-7. 11. 2003; Znaczna część ekologów zwracała uwagę, że budowa zagraża ekosystemowi Morza Azowskiego.

${ }^{26} \mathrm{Z}$ nieoficjalnych źródeł - Iwanow nie powiedział dziennikarzom, jakie dowody przywiózł do Kijowa - wiadomo, że była to mapa ZSRR z 1936 r. i kosmiczne zdjęcia, na których widać, że Tuzła jest z Rosją połączona; zob. Т. Силіна, Поговорили, dz. cyt. 
które przewiduje m. in. nienaruszalność granic istniejących między nimi. Kolejne miesiące we wzajemnych stosunkach upłynęły pod znakiem przygotowań do podpisania końcowego porozumienia w sprawie Morza Azowskiego i Cieśniny Kerczeńskiej.

Efektem kolejnych rund negocjacji było podpisanie 24 grudnia 2003 r. w Kerczu przez prezydentów Kuczmę i Putina Porozumienia między Ukraina $i$ Federacja Rosyjskeq o wspótpracy w eksploatacji Morza Azowskiego i Cieśniny Kerczeńskiej. W Porozumieniu znajduje się m. in. punkt mówiący o rozgraniczeniu Morza Azowskiego. Niejasny jest jednak status jaki miałyby mieć wody azowskie. Artykuł 1 mówi, że „Morze Azowskie i Cieśnina Kerczeńska są historycznie wewnętrznymi wodami Ukrainy i Federacji Rosyjskiej”, oraz że „Morze Azowskie podlega rozgraniczeniu”. Zdaniem głównego radcy ministra spraw zagranicznych Ukrainy Leonida Osawaliuka, te dwa zdania razem oznaczaja, że akwen dzieli się na wewnętrzne wody Ukrainy i wewnętrzne wody Federacji Rosyjskiej $^{27}$. Artykuł 1 mówi również o tym, że „regulowanie problemów związanych z wykorzystaniem Cieśniny Kerczeńskiej odbywać się będzie za porozumieniem stron", co oznaczać może zgodę Kijowa na wspólną eksploatację kanału. Dokładnym rozgraniczeniem akwenu zająć ma się wspólna ukraińsko-rosyjska delegacja. Artykuł 2 Porozumienia reguluje kwestie związane z przemieszczaniem się statków i okrętów wojskowych państw trzecich po akwenie. Zapisano w nim, że „statki handlowe i okręty wojskowe pływające pod banderą ukraińską lub rosyjską, i które eksploatowane sa w celach niekomercyjnych, posiadają swobodę żeglugi” oraz „statki handlowe pod banderą państw trzecich moga wypływać na wody Morza Azowskiego przez Cieśninę Kerczeńską, jeżeli udają się do portów ukraińskich bądź rosyjskich lub z nich wracają" i ,okręty wojskowe państw trzecich, które eksploatowane są w celach niekomercyjnych, mogą wypływać na Morze Azowskie przez Cieśninę Kerczeńska, jeśli udają się z wizytą do portu jednej ze Stron na jej zaproszenie lub za pozwoleniem drugiej strony"28. Prezydenci zwrócili się również $\mathrm{z}$ apelem o stworzenie wspólnej ukraińsko-rosyjskiej korporacji, która zająć miałaby się eksploatacją Kanału KerczeńskoJenikalskiego. Zwłaszcza ta ostatnia deklaracja wywołała falę ostrej krytyki nad Dnieprem, a entuzjazmu w Moskwie. Zdaniem jednak cytowanego już doradcy ministra spraw zagranicznych Ukrainy Osawaliuka Ukraina od dawna eksploatuje Kanał Kerczeńsko-Jenikalski

27 Т. Симіна, Росіяни не здаюоться, украйниі - здаюоть, „Азеркало тижня”, 27.12.20039.01.2004; Zob. M. Wojciechowski, Głosowanie w kacie, „Gazeta Wyborcza”, 2728.12.2003, P. Kościński, Koniec sporu o Tuzłe?, „Rzeczpospolita”, 29.12.2003.

28 Т. Силіна, Росіяни...,dz. суt. 
wspólnie nie tylko z Rosją, ale i innymi państwami, których statki przepływaja cieśninę. I wcale nie oznacza to, że statki te nie będa płacić za korzystanie z kanału ${ }^{29}$. Wiele wskazuje, zatem na to, że po raz kolejny strony interpretować będa Porozumienie po swojemu. Świadczy o tym także tekst artykułu 4, który mówi, że „Spory między Stronami, związane z tłumaczeniem i zastosowaniem tego dokumentu, rozwiązywane będa poprzez konsultacje i rokowania, a także innymi pokojowymi sposobami" ${ }^{30}$. Sukcesem strony ukraińskiej jest tu zgoda Moskwy na przeprowadzenie delimitacji Morza Azowskiego. Kijów nie uzyskał jednak takiej zgody w przypadku Cieśniny Kerczeńskiej.

Kolejny raz o podziale Morza Azowskiego i Cieśniny Kerczeńskiej rozmawiano w Moskwie na początku lutego 2004 r. Tę rundę rokowań śmiało można nazwać „małym przełomem”. Strona rosyjska otwarcie, bowiem zaczęła mówić o tym, że rozgraniczenie morza będzie miało miejsce łącznie $\mathrm{z}$ wyznaczeniem granic mórz terytorialnych obu stron, specjalnych stref ekonomicznych i szelfu kontynentalnego ${ }^{31}$. Rosyjska delegacja nie wyraziła zgody na podział Cieśniny Kerczeńskiej. Podczas spotkania dyplomaci dyskutowali nad sposobami wyznaczenia granicy. Moskwa wysuwała nowe koncepcje podziału, które jednak Kijów stanowczo odrzucał pozostając twardo przy swojej - podziału całego akwenu w oparciu o tzw. zasadę linii środkowej. Pozostawiałaby ona $65 \%$ morza po stronie ukraińskiej bardziej zasobnej $\mathrm{w}$ surowce $\mathrm{i}$ ryby ${ }^{32}$. W efekcie nie osiagnięto kompromisu. Zdecydowano również o porzuceniu planów stworzenia wspólnego konsorcjum, które zajmować miałoby się eksploatacją Kanału Kerczeńsko-Jenikalskiego. Następny „mały przełom” miał miejsce w końcu marca 2004 r., kiedy Moskwa zgodziła się, że granica powinna zostać przeprowadzona również w cieśninie. Wciąż jednak strony nie uzgodniły, w jaki sposób dokonać trzeba delimitacji ${ }^{33}$. Poza tym pozostaje jeszcze sprawa demarkacji granicy, co wydaje się być o wiele bardziej skomplikowanym procesem. Wattpliwości wywołuje także sposób ratyfikowania przez oba parlamenty dokumentów dotyczacych granic. Rosyjska Duma nalegała, aby Porozumienie o granicy państwowej z 31 stycznia 2003 r. i Porozumienie miedzy Ukrainq i Federacja Rosyjska o

\footnotetext{
29 Tamże.

${ }^{30}$ С. Солодкий, Керченський компроміс, „Аень”, 26.12.2003.

31 В. Кравченко, Азовська дільба: по братньому чи по справедливості?, „Азеркало тижня",07-13.02.2004.

32 Tenże, Азовський поділ: по братньому чи по справедливості - 2?, „Азеркало тижня”, 039.04.2004.

33 Tamże.
} 
wspótpracy w eksploatacji Morza Azowskiego i Cieśniny Kerczeńskiej podpisane 24 grudnia 2003 r., zostało ratyfikowane wraz z Umowa o Utworzeniu Wspólnej Przestrzeni Gospodarczej ${ }^{34}$, która na Ukrainie wywołała wiele kontrowersji. Niektórzy eksperci uważaja, iż Moskwa uzależniała ratyfikowanie Porozumień od ratyfikacji Umowy ${ }^{35}$.

Obecny stan rozmów rosyjsko-ukraińskich w kwestiach granicznych pozwala stwierdzić, że wiele dla uregulowania sytuacji zostało już zrobione. Dokonano delimitacji granicy lądowej i strony sa blisko tego samego w przypadku granicy morskiej. Wydaje się jednak, że aby sytuację unormować konieczne jest przeprowadzenie demarkacji. A na to brak po obu stronach przede wszystkim pieniędzy, ale również woli. Co równie istotne sposób w jaki tworzyła się i tworzy ukraińskorosyjska granica pokazuje, jaki jest faktyczny stan ukraińsko-rosyjskich stosunków. Jest to pasmo uników, podejrzeń, w zależności od sytuacji wzniosłych bądź bardzo ostrych wypowiedzi, a co najważniejsze zaniechania działań w najważniejszych sprawach. Doskonałym tego przykładem jest zamieszanie związane ze statusem Tuzły. Niejasnym do dziś pozostaje, kto podjął decyzję o rozpoczęciu budowy grobli: Moskwa czy Krasnodar? Nie dość tego, że „strategiczny partner” Ukrainy, jakim jest Federacja Rosyjska nie wyjaśnił władzom w Kijowie, kto rozpoczął budowę, to jeszcze ich o tym nie poinformowano, a stawiane przez ukraińskich dyplomatów pytania zwyczajnie lekceważono. Rada Najwyższa Ukrainy przyjęła specjalne oświadczenie do Rady Federacji i Dumy Rosji: „Jesteśmy głęboko zaniepokojeni informacjami, że strona rosyjska w trybie jednostronnym prowadzi zakrojone na szeroką skalę prace mające na celu przyłączenie części ukraińskiego terytorium wyspy Tuzła - do rosyjskiego brzegu Półwyspu Tamańskiego. (...) Rezerwujemy sobie prawo do działania z wykorzystaniem wszystkich norm międzynarodowych dla obrony integralności terytorialnej Ukrainy i nietykalności jej granic" ${ }^{36}$. Moskwa najpierw długo milczała, potem tłumaczyła, że z budowa grobli nie ma nic wspólnego, a gdy prezydent Kuczma próbował skontaktować się z prezydentem Putinem, na Kremlu odpowiedziano, że prezydent jest właśnie w zagranicznej podróży i nie

\footnotetext{
34 WPG utworzyły Białoruś, Kazachstan, Rosja i Ukraina. Umowa o utworzeniu WPG przewiduje $\mathrm{m}$. in. dostosowywanie prawodawstwa, sformowanie związku celnego, a strefa wolnego handlu WPG będzie strefa ,na pół wolnego handlu” - z wolnego obrotu towarami, bowiem wyłączono ogromną ilość towarów. Co rosyjscy, białoruscy i kazachscy politycy podkreślają, że to dopiero początek integracji. Rozważane jest także wspólne wstapienie do WTO.

35 Т. Силіна, Співучасники, „Азеркало тижня”, 24-30.04.2004.

${ }^{36}$ P. Kościński, dz. cyt.
} 
można się z nim skontaktować. A w tym samym czasie moskiewskie $i$ krasnodarskie gazety pisały, że trzystu Kozaków Tamańskich czeka na moment, gdy grobla dojdzie do wyspy, by na nią wejść, zająć i ogłosić terytorium rosyjskim ${ }^{37}$.

Obecnie po podpisaniu i ratyfikacji Porozumienia z 24 grudnia 2003 r. wiadomo, że głównym celem Moskwy było wywarcie presji na Kijów w sprawie podziału azowskiego akwenu. Przy okazji sporu Kreml poruszał newralgiczny we wzajemnych stosunkach (zwłaszcza dla Ukrainy) temat - zabezpieczenia Ukrainy dostawami rosyjskiego gazu, co czyniło ukraińskie stanowisko wobec problemu granicy bardziej elastycznym ${ }^{38}$. Część obserwatorów uważa, że konflikt o Tuzłę wpisuje się w jeden ciąg wydarzeń, które miały miejsce w Rosji (aresztowanie Michaiła Chodorkowskiego ${ }^{39}$ czy też zamieszanie wokół dymisji szefa prezydenckiej administracji Aleksandra Wołoszyna) i miał związek z wyborami parlamentarnymi i prezydenckimi w Rosji. W obliczu przedwyborczej walki konflikt o Tuzłę „pobudzał” wyborców. Winę za taka politykę Rosji wobec Ukrainy ponosi jednak także sama Ukraina. Kijów w swoich stosunkach z Moskwą zajmuje pozycje startową, która od razu spycha go do defensywy. Sprawa Tuzły i Morza Azowskiego wydawała się być od początku jasna: są dokumenty, które jednoznacznie mówią o przynależności wyspy do Ukrainy, a prawo międzynarodowe zezwalało Ukrainie na jednostronne wyznaczenie granicy. Decyzja Gabinetu Ministrów Ukrainy z 16 listopada 2002 r. takie wyznaczenie zostało nawet uchwalone. Dla zafiksowania tego stanu rzeczy wystarczyło tylko zarejestrować tę decyzję w Sekretariacie Głównym ONZ. Na ten krok ukraińskich polityków już jednak nie było stać ${ }^{40}$.

Spór o wysepkę zdominowal również specjalne obrady Rady Najwyższej Ukrainy na temat stosunków ukraińsko-rosyjskich, które odbyły się 22 października 2003 r. W obradach tych wzią udział także przedstawiciel Federacji Rosyjskiej, zastępca przewodniczącego Rady Federacji Rosji - Walerij Goregliad. Tylko on w swoim wystapieniu ani razu nie wspomniał o budowie grobli i związanym $z$ tym zamieszaniu całkowicie ignorując przemówienia ukraińskich kolegów. Świadczy to o braku woli ze strony Moskwy na rozwiązanie sporu granicznego z Ukrainą. Ciężko też stwierdzić, iż chęci rozwiązania kwestii granicznych

37 W. Radziwinowicz, Ukraina jako gubernia, dz. cyt.

38 В. Княжанський, Тузлинський синхрон або чіна газової конщесій, „Аень”, 5.11.2003.

39 Chodorkowski to najbogatszy człowiek w Rosji 2002 r. Do czasu, gdy został aresztowany był prezesem koncernu Łukoil. Oficjalnie wspierał finansowo opozycyjne wobec Kremla partie.

40 T. Силіна, Поговорили, dz. суt. 
nie brakuje politykom ukraińskim. Bo poza buńczucznymi i populistycznymi wypowiedziami, które i tak często w ustach tych samych osób brzmią inaczej (w zależności do kogo są adresowane), Kijowa nie stać na zdecydowane działania. Ukraińskie władze prezentują często w swoim zachowaniu wobec północno-wschodniego sąsiada kompleksy wyniesione jeszcze z czasów rosyjskiego i sowieckiego zniewolenia. Kijów wciąż ogląda się na Moskwę podejmując kluczowe decyzje w polityce zewnętrznej. Co prawda ukraińska opozycja określając stan stosunków rosyjsko-ukraińskich stawia sprawę jasno i bez zakłamania. Jeden z jej liderów, Borys Tarasiuk - przewodniczący parlamentarnego komitetu ds. integracji europejskiej, podczas obrad stwierdził, że to, co ma obecnie miejsce w relacjach Ukrainy z Rosją nie ma nic wspólnego z demokracją. Spotkania i konsultacje między państwami określił jako „wąskoelitarne związki i niepubliczne procedury uzgadniania interesów i przyjmowania decyzji" ${ }^{41}$. Problem jednak polega na tym, że w sprawach polityki zewnętrznej kraju, ukraińska opozycja ma bardzo mało do powiedzenia. A jeśli chodzi o jej ewentualny wpływ na stosunki z Rosja to można powiedzieć, że jest żaden. Cytowany wyżej Tarasiuk nawet, kiedy zajmował posadę ministra spraw zagranicznych Ukrainy właściwie nie zajmował się kontaktami z Moskwa. Zadanie to prezydent Kuczma powierzył Anatolijowi Orłowi z Departamentu Polityki Zagranicznej Administracji Prezydenta - politykowi zdecydowanie prorosyjskiemu.

Konflikt o Tuzłę zmusił ekspertów i polityków po obu stronach do refleksji nad stanem wzajemnych stosunków. Okazją do tego była transmitowana na żywo debata telewizyjna na temat sytuacji w Cieśninie Kerczeńskiej, która odbyła się 24 października 2003 r. i w której udział wzięli politycy, dziennikarze $\mathrm{i}$ analitycy z Rosji i Ukrainy ${ }^{42}$. Zdaniem jednego z uczestników dyskusji, przewodniczącego ukraińskiej partii Sobor - Anatolija Matwijenki, rzeczowych rozmów właściwie nie było. Gdy dziennikarz rosyjskiej sekcji Radia Swoboda Witalij Portnykow pytał Dmitrija Rogozina, osobę bliska prezydentowi Putinowi, w jakich wyborach brali udział mieszkańcy Tuzły w 1991 r.: do Rady Najwyższej USRR czy RFSRR, ten odpowiedział, że do ZSRR. Rosjanie uczestniczący w programie $z$ uporem twierdzili, że żadnych granic między Ukrainą i Federacja Rosyjską nie ma i nie będzie, a Tuzła to „wiecznie rosyjska ziemia”. Poseł Dumy - Aleksiej Mitrofanow powiedział, że „Ukraina w ogóle nie jest niezależnym państwem” więc, o

${ }^{41}$ Н. Трофімова, Криза довіри, „Аень”, 23.10.2003.

42 А. Матвіснко, Як до нас ставлятоться в Росії $і$ як до чвого ставитися нам ?, „Аень”, 7.11.2003. 
jakich normach prawa międzynarodowego może być mowa? Wywód Mitrofanowa spuentował inny poseł Dumy Anatolij Szyszkariow, słowami: „i do czego tu jakaś Ukraina?”. Nie wszyscy jednak ze strony rosyjskiej wypowiadali się tak ordynarnie. Część z nich domagała się rychłego oddania wysepki Rosji, ale inni podkreślali, że budowa grobli przyniesie interesom rosyjskim tylko szkodę. Najtrafniej poglądy te przedstawił Alfred Koch: „Jestem przekonany, że interesy Rosji nie ograniczaja się do Tuzły. Do Rosji powinny faktycznie należeć dyplomatycznie, de iure, może jeszcze jakoś inaczej - i Krym, i Chersoń, i Mikołajów, i Odessa. I to jest nasz strategiczny cel. Wisiała tam będzie rosyjska czy ukraińska flaga nie jest ważnym. Ważnym by faktycznie te ziemie były rosyjskie, które będą liczyć się z naszymi interesami, by tam był obecny rosyjski kapitał i Rosjanie. Dla osiagnięcia tego celu środki dyplomatyczne zostały wyczerpane. Pozostaje jedyna droga - to ekonomiczna ekspansja, to faktyczne wykupienie tych ziem, nieruchomości, infrastruktury"43.

Spory graniczne wpisują się w szerszy kontekst stosunków między krajami. Pomimo tego, że szczelna granica państwowa jest podstawowym atrybutem istnienia państwa, Ukraina i Federacja Rosyjska nie potrafiły uporządkować sytuacji na wspólnym pograniczu już 13 lat. Jednocześnie elity rządzące obu krajów wykorzystują ten temat do pozyskiwania jak największej liczby głosów podczas kolejnych wyborów, a także w trakcie rozmów dotyczących szerokiego spektrum wzajemnych relacji (nośniki energii, prywatyzacja, polityczne poparcie). Innymi słowy władze rosyjskie i ukraińskie „handluja” granicą swych krajów. Taki sposób prowadzenia polityki przez postradzieckich przywódców prowadzi donikąd - powstaje wiele zamieszania, a problemy pozostają.

Po dojściu do władzy na Kremlu przez Putina, a zwłaszcza po wydarzeniach z 11 września 2001 r., ma miejsce dosyć szybkie umocnienie pozycji Rosji na arenie międzynarodowej. W tym samym czasie kolejne skandale polityczne nad Dnieprem ${ }^{44}$, które izolują Kijów od Zachodu, jednocześnie spychają ją w stronę Rosji. Rozwój wydarzeń według takiego scenariusza może doprowadzić do tego, że Ukraina stanie się wyłączną strefą wpływów Rosji. A jak wiadomo Rosja jest w

43 Тузла: з ким маємо справу?, „Аень”, 31.10.2003; Pełny tekst telewizyjnej dyskusji znajduje się na stronie internetowej gazety „Аень”:

http://www.day.kiev.ua/2003/196/nomer.htm

${ }_{4}$ Np. tzw. „skandal kasetowy”, który wstrząsnął Ukrainą już w roku 2000, kiedy o zlecenie zabójstwa dziennikarza internetowego portalu Ukrainska Prawda oskarżano prezydenta Kuczmę czy związany z rzekomą sprzedażą Irakowi przez Ukrainę systemów radarowych Kolczuga. 
stanie odbudować swoja pozycję imperialna tylko mając pod swoja kontrolą Ukrainę. Dowodem na takie zagrożenie jest ciąły wzrost nastrojów imperialnych w Rosji. Anatolij Czubajs - niegdyś znany rosyjski reformator, a obecnie szef państwowej spółki Zjednoczone Energetyczne Systemy Rosji, zaliczany do rosyjskich liberałów - użył podczas wykładu dla studentów prestiżowego petersburskiego Uniwersytetu Inżynieryjno-Ekonomicznego takich słów: „Ideologia Rosji na cała dająca się przewidzieć przyszłość winien się stać imperializm liberalny. Misją zaś Rosji jest stworzenie liberalnego imperium. Taki wniosek płynie z naszej historii najnowszej. To właśnie jest nasz cel - naturalny, organiczny, strategiczny, właściwy dla Rosji i historycznie, i geopolitycznie, i moralnie. To w końcu jest zadanie na taką skalę, jaka pomoże naszemu narodowi ostatecznie przezwyciężyć kryzys duchowy, rzeczywiście go zmobilizuje i zjednoczy" ${ }^{45}$. Czubajs dodał jednak, że Moskwa nie powinna sięgać po ziemie sąsiadów, a należy jedynie wspomagać gospodarczo ekspansję Rosji w krajach b. ZSRR. Trzeba przy tym pamiętać, iż jest to stanowisko rosyjskich liberałów, czyli frakcji spośród rosyjskich sił politycznych najbardziej przychylnej niepodległości Ukrainy. Obawy o powrót Rosji na droge imperialną wyraża także część polityków i obserwatorów na Ukrainie. O zachowanie prawdziwej niepodległości boi się ekspert Ukertransnafty spółki zarządzającej ukraińskimi rurociagami - i dyrektor Międzynarodowego Centrum Strategia - 1 Mychajło Honczar: „Od dziesięciu lat uczestniczę w negocjacjach z Rosjanami na temat naszych rurociagów i widzę jak oni się zmieniaja, dosłownie z miesiąca na miesiąc. Gdzieś od roku stali się wyjątkowo twardzi i nieustępliwi. Nie tylko, dlatego że taki przykład dają im Amerykanie. To jest już inne państwo. Rosja znowu zaczęła wierzyć w siebie. Dla Waszyngtonu Rosja nie jest już krajem prowadzącym „brudną wojnę” w Czeczenii, lecz ważnym partnerem w walce $z$ terroryzmem. Na Kremlu dobrze wiedza, że Zachód nie zamierza się wtrącać do sporów Moskwy z dawnymi braćmi radzieckimi" ${ }^{46}$.

Realna niepodległość Ukrainy zagrożona jest także, dlatego że ukraińska elita nie ma prawdziwej i efektywnej koncepcji stosunków z Rosją. Wpływaja na nią kolejne kampanie wyborcze czy też częste i nieoczekiwane zmiany na kluczowych posadach w państwie. Nawet, jeśli strategie rozwoju współpracy z Rosją są w ukraińskim ministerstwie spraw zagranicznych przygotowywane, to okazują się one nie do

\footnotetext{
45 W. Radziwinowicz, Chcieliby imperium, „Gazeta Wyborcza”, 22-23.11.2003.

${ }^{46}$ Tamże.
} 
zrealizowania. Dotyczy to zresztą całości polityki zagranicznej Ukrainy. Kijów od lat uchyla się od zdecydowanej odpowiedzi na strategiczne pytania. Choćby o to, z kim miałaby Ukraina się integrować - ze wschodnim sąsiadem czy Europa. Wciąż poszukuje jakichś kompromisów, próbuje przechytrzyć a to Moskwę, a to Brukselę. I w końcu doszła do punktu, w którym rzecz idzie o całość jej terytorium. A tam gdzie idzie o choćby metr kwadratowy obszaru, kompromisów już być nie może. Taka polityka lawirowania przynosiła efekty w początkach niezależnego bytu. Nadszedł już jednak najwyższy czas by elity rządzące nad Dnieprem zrozumiały, że jeśli Ukraina nie chce, z jednej strony pozostać poza procesem integracji europejskiej, a z drugiej stracić szansy na wykorzystanie możliwości, jakie daje przejrzysta współpraca z Rosja (przede wszystkim w dziedzinie ekonomicznej), to Kijów nie powinien pozwalać sobie na sprzeczne deklaracje w Moskwie, Brukseli, Astanie, Londynie, Mińsku czy Paryżu. Obserwując poczynania ukraińskich elit w kwestii Wspólnej Przestrzeni Gospodarczej (WPG), wydaje się, że jeszcze długo Kijów będzie lawirował między wschodnimi i zachodnimi partnerami. Oficjalnie strategicznym celem Kijowa jest pełna integracja z Unią Europejską. Bruksela jednak szanse na osiągnięcie tego celu, na razie ocenia wstrzemięźliwie. Wywołuje to falę krytyki pod adresem UE ze strony władz ukraińskich, które powtarzają, że dlaczego Ukraina ma spełniać kryteria członkowskie, dostosowywać swoje prawodawstwo do unijnego czy reformować gospodarkę, jeśli Unia Ukrainy nie chce. Zdaniem ukraińskich elit rządzących póki UE nie daje Kijowowi obietnicy członkostwa, Ukraina powinna postawić na rozwój współpracy w przestrzeni postradzieckiej. Z dużą dozą prawdopodobieństwa stwierdzić można, iż WPG przekształci się z czasem w strukturę na wpół umarła - na wzór WNP i innych organizacji powstałych na zrębach ZSRR i tym samym stracone zostaną kolejne lata na uporządkowanie relacji między jej państwami. Problem jednak polega na tym, że Bruksela obserwując dziwne i niezrozumiałe ruchy Kijowa - chęć dostosowania swojego prawodawstwa z innymi członkami WPG i koordynacji działań w ramach wstąienia do WTO, ataki na niezależne media, i wreszcie nieumiejętność w ciagu 13 lat uporządkowania sytuacji na swojej granicy państwowej $^{47}$ - nie zechce podpisać z Ukrainą choćby Układu Stowarzyszeniowego.

Szansą na uregulowanie sporu z Rosja, a także na osiagnięcie wymarzonego przez zdecydowaną większość Ukraińców celu - integracji

47 Ukraina toczy także spór graniczny z Rumunią o Wyspę Wężową. Oprócz tego nieuregulowano sytuacji na granicach z Białorusią i Mołdawia. 
z UE, są wybory prezydenckie i zwycięstwo w nich kandydata opozycji. Dla Polski, dla całej Europy niezwykle ważnym jest by były to wybory uczciwe i przejrzyste. Od wyborów zależy czy Ukraina pójdzie w końcu drogą szybkich reform, czy zechce uniezależniać się od Rosji, demokratyzować. A od demokratyzacji i niezależności Ukrainy zależeć będzie w pewnej mierze rozwój sytuacji w Rosji, a tym samym na całym obszarze b. ZSRR. Dalszy bieg wydarzeń związanych z rozgraniczeniem Ukrainy i Federacji Rosyjskiej będzie papierem lakmusowym wzajemnych stosunków. Jeśli strony wykażą odpowiednio wiele silnej woli by uporządkować ten problem, jest wielce prawdopodobne, że będziemy mieć do czynienia z nową jakością w stosunkach Kijowa i Moskwy. Dalsze zaniechania z obu stron mogą doprowadzić do tego, że nowa granica wschodnia Unii Europejskiej pozostanie na długie lata kolejną „kurtyną” w Europie. 